\title{
Characteristics of calcium intake in nursing home residents in Zagreb
}

\section{Selma Cvijetić ${ }^{*}$, Luka Bashota², Zvonimir Šatalić}

\author{
'Institute for Medical Research and Occupational Health, Department of Occupational \\ and Environmental Medicine, Ksaverska cesta 2, Zagreb, Croatia \\ ${ }^{2}$ University of Zagreb, Faculty of Food Technology and Biotechnology, Pierottijeva 6, Zagreb, Croatia \\ *Corresponding author: Phone: +385 14682 500; E-mail: cvijetic@imi.hr
}

\section{Abstract}

Elderly people, especially those who live in nursing homes, are at high risk for getting osteoporosis and bone fractures. Knowing that an adequate calcium intake is important for prevention and therapy of osteoporosis, we aimed to estimate calcium intake in old people living in nursing homes in Zagreb. In a cross-sectional study, calcium intake was estimated using previously validated food frequency questionnaire especially designed for calcium intake, among 292 nursing homes residents (232 women and 60 men), mean age $82.4 \pm 6.5$ years. Mean dietary calcium intake in men was $653 \pm 297 \mathrm{mg} /$ day and in women $528 \pm 279 \mathrm{mg} /$ day $(\mathrm{p}=0.004)$. Only $10 \%$ of women and no men were taking calcium supplements. Calcium intake below the $750 \mathrm{mg} /$ day was present in $67.3 \%$ of men and $77.5 \%$ of women. Very low calcium intake, below the half of the recommended value, was present in $18.3 \%$ of men and $31.0 \%$ of women. Milk and dairy products were the main source of calcium intake in our study and contributed more than $80 \%$ of total daily calcium intake. No significant correlation was found between the body mass index and calcium intake in both genders. We conclude that the mean calcium intake in nursing home residents was below the recommended values.

Key words: calcium intake, elderly people, nursing homes

\section{Introduction}

The number of elderly people in most populations worldwide is increasing, and part of that population needs to be taken care of in institutions such as nursing homes. Nursing homes are faced with a very heterogeneous population of residents, which is reflected in various and specific nutritional needs. Many residents living in nursery homes are chronically ill and are often prescribed different medication. All this may affect their nutritional status, together with other problems, which are often presented in the elderly, such as anorexia, lack of teeth, dementia and depression (Zelenik, 2016). These factors can have a significant impact on the nutritional status of the elderly, who are at higher risk of malnutrition and sarcopenia.

Aged residents of nursing homes are at particularly high risk of osteoporosis. The consequences of osteoporosis for individual nursing home residents are an increased risk of fractures, pain and disability (Zarowitz, 2014). More than $80 \%$ of institutionalized old people have osteoporosis and approximately $40 \%$ of them had hip fractures (Duque, 2016). Many of them need continuing care, and it has been show that the mortality after hip fracture 
is nearly $20 \%$ (Johnell, 2006). One of the most important factors in preventing bone loss is an adequate calcium intake. Calcium is best absorbed through the foods and it has been shown that calcium from well-balanced diet is better utilized than that from supplements alone (Papaloanou, 2015). But most results show that calcium and vitamin $D$ intake in nursing homes in Croatia are far below the recommended intake (Rumbak, 2010; Mandić, 2014). However, the literature review addressed the complexity of determining what an adequate intake is for elderly. The recommendations are ranging from $500 \mathrm{mg}$ to $1500 \mathrm{mg}$ of dietary calcium for elderly (Nordic Council of Ministers, 2004; Yates, 1998; Department of Health and Ageing, 2006; Tang, 2007). Moreover, there is not always a clear legislation regulating food quality control in nursing homes. Many countries rely on guidance for the diet for older people which can be used to prepare menus for nursing homes (Vranešić Bender, 2011). Therefore, it has not yet been formalized whether the existing recommendations can be applied strictly to older people.

The aim of the study was to investigate dietary calcium intake in elderly population who live in nursing homes in Zagreb and to describe the characteristics and factors associated with their calcium intake.

\section{Materials and methods}

The study protocol was previously described in detail in the publication about the physical activity and bone density in the same study group (Cvijetić, 2019). Briefly, the study population comprised residents of six public nursing homes for older people in Zagreb, who had been institutionalized for more than one year. Informed consent was obtained from all subjects included in the study. Participants were recruited on a voluntary basis and the study was approved by the Ethics Committee of the Institute of Medical Research and Occupational Health.

\section{Questionnaire}

A validated, quantitative food frequency questionnaire (FFQ) was used to determine the average daily calcium intake (Šatalić, 2007). The amount of calcium intake was calculated using national food composition tables (Kaić Rak, 1990). The short calcium FFQ was developed from the draft version based on the FFQs used in the previous studies involving schoolchildren and university students (Colić Barić, 2002, 2004; Šatalić, 2004). The draft version was applied on 100 subjects, allowing the creation of the final short calcium FFQ with 27 items which provided most of the total calcium intake. Those 27 items contributed to $95 \%$ of total calcium intake on the previous FFQ. The questionnaire comprised 4 food groups rich with calcium, with different number of foods in each group: 1.) Diary products: milk, yogurt, fruit yogurt, cheese (semi-hard, fresh and processed), pudding, ice-cream; 2.) Fruits: apples and oranges; 3) Vegetables: spinach, beans; 4) Canned fish: sardines. The intake of bread and water was also included into the questionnaire. The menus in different nursing homes were relatively similar and some foods from the questionnaire, like canned fish, ice cream and pudding, were rarely present in the diet. Therefore, in the data analysis, those foods were categorized as "other".

\section{Anthropometry}

Height and weight were measured on a portable stadiometer and scale (Model TTM; Zagreb, Croatia) and were rounded to the nearest $0.5 \mathrm{~cm}$ and $0.5 \mathrm{~kg}$, respectively. The body mass index (BMI) was calculated as weight $(\mathrm{kg})$ divided by the square of height $\left(\mathrm{m}^{2}\right)$.

It has been suggested that the difference in calcium intake between the genders may be partly attributed to differences in their body size. So, when calcium intake is controlled by body weight, the mean recommended values for calcium are 18.1 to $18.5 \mathrm{mg} / \mathrm{kg}$ body weight per day (Uenishi, 2002). Therefore, we considered differences in body weight between men and women when comparing calcium intake between them.

\section{Statistics}

The results are shown as mean \pm standard deviation. The distribution of variables was tested using 
the Kolmogorov-Smirnov test. Since most variables were distributed normally, parametric functions were used in data analyses. Differences between men and women were tested using the t-test. Association between continuous variables were analysed with correlation matrices. All calculations were done with the Statistica (Dell Inc, Tulsa, OK) ver.13.0 software. The level of significance was set at $p<0.05$.

\section{Results and discussion}

The mean age of participants was 82 years (Table 1). The mean duration of their stay in the nursing homes was approximately 10 years. Women had significantly higher BMI than men ( $p=0.001$ ). According to BMI, $18.5 \%$ of women and $38.3 \%$ of men had normal weight, $62.1 \%$ of women and $50.0 \%$ of men were overweight, while $19.4 \%$ of women and $8.3 \%$ of men were obese. No participant had a BMI below 18.0.

TABLE 1. Age, anthropometry and calcium intake in nursing homes residents

\begin{tabular}{l|l|l|l}
\hline & $\begin{array}{l}\text { Men } \\
\text { (N 60) }\end{array}$ & $\begin{array}{l}\text { Women } \\
\text { (N 232) }\end{array}$ & $\mathbf{p}$ \\
\hline Age (yrs.) & $82.7 \pm 6.3$ & $82.4 \pm 6.6$ & n.s. \\
\hline Height (cm) & $175.5 \pm 8.2$ & $160.3 \pm 5.8$ & $<0.001$ \\
\hline Weight (kg) & $79.3 \pm 8.9$ & $70.3 \pm 8.6$ & $<0.001$ \\
\hline BMl (kg/m²) & $25.8 \pm 3.1$ & $27.3 \pm 3.3$ & 0.001 \\
\hline $\begin{array}{l}\text { Dietary } \\
\text { calcium intake } \\
\text { (mg/day) }\end{array}$ & $653 \pm 296$ & $528 \pm 279$ & 0.004 \\
\hline $\begin{array}{l}\text { Supplemental } \\
\text { calcium intake } \\
\text { (mg/day) }\end{array}$ & $/$ & $\begin{array}{l}355 \pm 118 \\
(\mathrm{~N} \mathrm{10)}\end{array}$ & $/$ \\
\hline
\end{tabular}

The mean dietary calcium intake in men was $653 \pm 296 \mathrm{mg}$ per day and in women $528 \pm 279 \mathrm{mg} /$ day $(p=0.004)$ (Table 1). Among women, $10 \%$ were taking calcium supplements and $15 \%$ vitamin $D_{3}$, while no man was taking calcium or vitamin $D$ supplements. Calcium intake below EFSA recommended values (750 mg/day) was found in $67.3 \%$ of men and $77.5 \%$ of women (Table 2). Very low calcium intake $(<375 \mathrm{mg} /$ day, which is half of the recommended value) was found in $31.0 \%$ of women and $18.3 \%$ of men. Calcium intake higher than $1000 \mathrm{mg} /$ day was determined in $5.6 \%$ of women and $13.3 \%$ of men ( $p=0.039$ ).

TABLE 2. Dietary calcium intake below EFSA recommended values

\begin{tabular}{l|l|l|l}
\hline $\begin{array}{l}\text { Dietary calcium } \\
\text { intake }\end{array}$ & $\begin{array}{l}\text { Men } \\
\mathbf{N}(\%)\end{array}$ & $\begin{array}{l}\text { Women } \\
\mathbf{N}(\%)\end{array}$ & $\mathbf{p}$ \\
\hline$\geq 750 \mathrm{mg} /$ day & $20(32.7)$ & $52(22.5)$ & n.s. \\
\hline$<750 \mathrm{mg} /$ day & $40(67.3)$ & $180(77.5)$ & n.s. \\
\hline$<375 \mathrm{mg} /$ day & $11(18.3)$ & $72(31.0)$ & n.s. \\
\hline Total & $60(100.0)$ & $232(100.0)$ & \\
\hline
\end{tabular}

In our elderly institutionalized participants, dietary calcium intake was somewhat lower than the recommended values, both in men and women. There are many recommendations for an adequate daily calcium intake for people over 50 years: from 700 mg/day in the United Kingdom, 800 mg/day in Scandinavian countries to $1200-1300$ mg/day in the United States and Australia (Warensjö, 2011). The European Food Safety Authority (EFSA) has issued its recommendations at which the adults over the age of 24 should have $750 \mathrm{mg}$ of calcium per day (EFSA, 2017). In Croatia, calcium intake recommendations are set to $800 \mathrm{mg} /$ day regardless of the gender or age (Croatian Official Gazette, 2011).

Our results on calcium intake in elderly people are similar to previous research on the diet quality in nursing home residents in Zagreb, which showed that approximately $53 \%$ of residents had a calcium intake below $50 \%$ of recommended value and that only $3.2 \%$ of participants had an adequate calcium intake (Rumbak, 2010). In the study on adequacy of nutrition in elderly residents and non-residents of nursing homes in Croatia, Colić Barić (2006) found that all meals provided adequate amount of micronutrients, with exception of calcium, which was $63 \%$ of DRI. In the study group of 120 adults from eastern Croatia, aged 33.8 years, the average daily dietary intake of calcium was 661 mg/day (Mandić-Puljek 2005). It has also been shown that menus in nursing homes in Croatia are in accordance with the recommendations regarding the 
energy value of the meal and the energy share of the macronutrients, but the calcium content is less of DRI values (Keser, 2005; Ćurin, 2006).

Calcium intake in our participants was somewhat better when compared to similar studies outside the country. In 93 elderly Thai women who were living in nursing homes, dietary calcium intake was 322.3 mg/day (Kruavit, 2012), while in participants from nursing home in China, the intake was 355.4 mg/day (Meng, 2016). In institutionalized elderly people from Southeast Spain, the intake of many nutrients, including calcium and vitamin D, was low in $>80 \%$ of participants (Rodríguez-Rejón, 2019).

The recommended values for calcium intake are set up according to the most important physiological effect for maintaining normal plasma calcium levels, which is movement of calcium into or out of the bones. It has been shown that calcium intake less than $700 \mathrm{mg} /$ day in women was associated with increased risk of losing bone calcium and getting an osteoporosis (Warensjö, 2011). However, an additional higher calcium intake does not actually appear to lower a person's risk for osteoporosis, therefore it is not recommended to increase calcium intake significantly above these levels for the bone loss prevention (Warensjö, 2011). Evidence suggests that calcium intake of as little as $300 \mathrm{mg}$ per day, in the absence of vitamin D deficiency, is unlikely to result in clinically significant bone loss (Beckerleg, 2017). Therefore, we think that dietary calcium intake between 528 and 653 mg per day in our participant did not pose the risk for bone density loss, depending, of course, of other risk factors like physical activity, other diseases and medications.

It is noticeable that a small percentage of our female participants and also no male participant, was taking calcium or vitamin D supplementation, which is similar to Thai study (Kruavit, 2012). However, there is growing concern that calcium supplements can lead to unwanted effects such as kidney stones or cardiovascular disorders, especially in elderly people (Bolland, 2015) and that the benefit of calcium supplements in preventing fractures is small (Zhao, 2017). That is why elderly people are recommended to increase the intake of dietary calcium by increasing the consumption of foods such as milk and dairy products (Bauer, 2013).

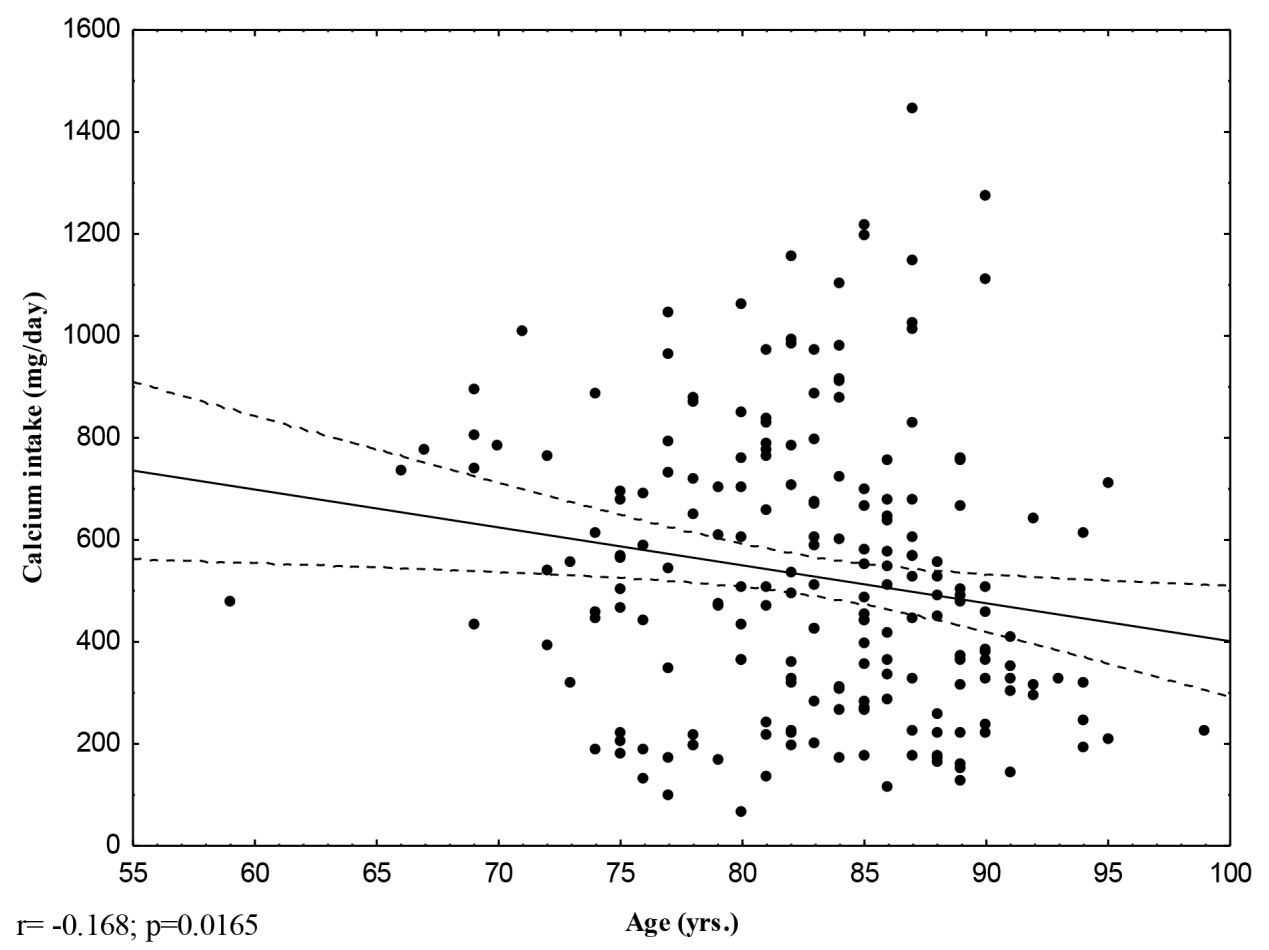

FIGURE 1. Correlation between calcium intake and age in women 


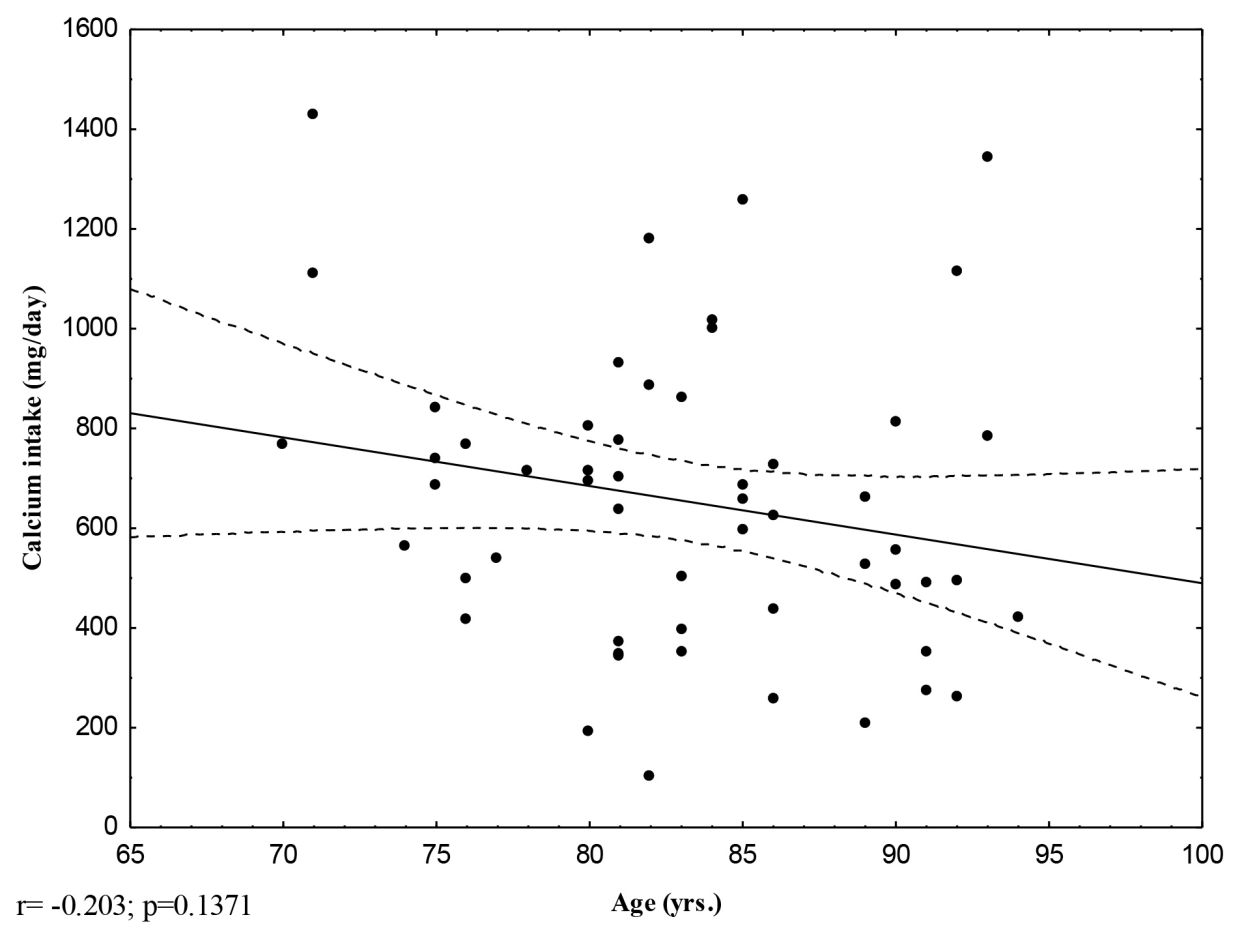

FIGURE 2. Correlation between calcium intake and age in men

Dietary calcium intake correlated negatively with the age, but that correlation was significant only in women (Figures 1 and 2). Although a significant correlation between the age and BMI was found in women ( $p=0.003$ ), there was no significant correlation between $\mathrm{BMI}$ and the calcium intake in both genders. When presents dietary calcium intake according to the body weight (kg), $90 \%$ of men had a calcium intake below $18.1 \mathrm{mg} / \mathrm{kg}$, while $85.8 \%$ of women were below $18.5 \mathrm{mg} / \mathrm{kg}$. Calcium intake in our participants decreased with age, which is similar to findings of some past studies
(Mandić-Puljek, 2005; Genari, 2001). Decrease in dietary calcium intake could be the result of the overall decrease in calorie intake, since elderly people may have poor appetite or some illnesses that decrease the sense of hunger. Additionally, calcium intake according to body weight was satisfactory in only $10 \%$ of men and in $14 \%$ of women who took part in this study. Bearing in mind that nearly $85 \%$ of women and $67 \%$ of men were overweight or obese, we think that estimation is more a consequence of high prevalence of increased body weight than of low calcium intake.

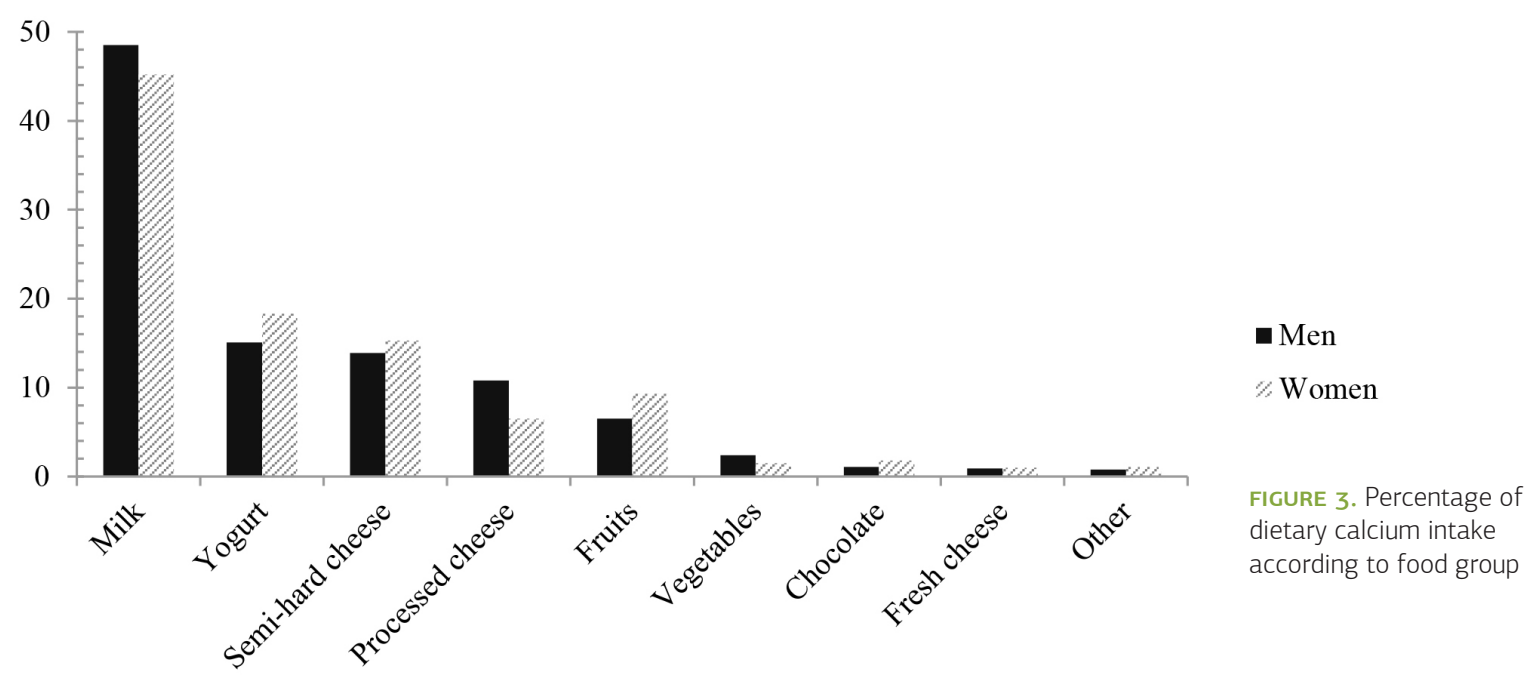


In both genders, the highest proportion of dietary calcium consumption has originated from milk (48.5\% in men and $45.2 \%$ in women), followed by yogurt (15.1\% in men and $18.3 \%$ in women) and semi-hard cheese (13.9\% in men and $15.3 \%$ in women) (Figure 3). As a source of calcium intake, processed cheese was on the fourth place in men, while fruits were on the fourth place in women. Men took significantly more calcium from vegetables than women $(p<0.001)$. The lowest calcium intake in both genders was from fresh cheese and "other" foods. A similar distribution of calcium-rich food was found in the group of participants with low calcium intake ( $<750 \mathrm{mg} /$ day) and in those with higher calcium intake (>750 mg/day). Milk, yogurt and semi-hard cheese were the most common sources of calcium intake in both groups.

As expected, milk and dairy products made the greatest contribution to the calcium intake in our study. More precisely, nearly $50 \%$ of the total calcium came from milk, which is twice as much as from other dairy products. Milk and milk products contributed more than $80 \%$ of the total daily calcium intake, which is much higher than in previous study on younger population from eastern Croatia (Mandić-Puljek, 2005). This indicates an adequate presence of dairy products in menus in nursing homes in Zagreb.

One of the limitation of this study was the lack of data about vitamin D intake, since the absorption and bioavailability of calcium is dependent on vitamin D status. However, food is a minor source of vitamin $D$ and even though someone has an adequate vitamin $\mathrm{D}$ intake, it does not necessarily result in vitamin D sufficiency. Another limitation was a relatively low recruitment rate (around $33 \%$ ) in our study, but our participants were uniform according to the age and consequently comparable to other studies dealing with nutrition in elderly people.

\section{Conclusions}

In elderly participants who live in nursing homes in Zagreb, daily calcium intake was significantly higher in men than in women although neither of them had an adequate mean calcium intake according to the recommended values. A very small percentage of women and no men took calcium or vitamin D supplements. Although the presence of dairy products, as the most important source of calcium intake, was satisfactory in nursing homes included in this study, in our opinion a clear legislation and systematic quality control of nutrition in nursing homes is still needed in order to accomplish better overall calcium intake for their residents.

\section{Acknowledgements}

The authors thank the residents and personnel of the nursing homes: Centar, Ksaver, Maksimir, Park, Sveti Josip and Trešnjevka for their participation, help and support.

The study was supported by the Institute for Medical Research and Occupational Health (Project "Bone mineral density and fracture risk in older institutionalized people").

\section{Karakterizacija unosa kalcija među korisnicima domova za starije osobe u Zagrebu}

\section{Sažetak}

Stariji ljudi, pogotovo oni koji žive u domovima za starije osobe, imaju visok rizik obolijevanja od osteoporoze te posljedično lomova kostiju. Obzirom da je primjeren unos kalcija važan čimbenik u prevenciji i liječenju osteoporoze, u ovom presječnom istraživanju smo analizirali unos kalcija u osoba koje žive u domovima za starije osobe u Zagrebu. Korišten je prethodno validirani upitnik, dizajniran za procjenu unosa kalcija. Sudjelovale su 292 osobe, 232 žene i 60 muškarca, prosječne dobi 82,4ะ6,5 godina, a podaci o unosu kalcija su dobiveni upitnikom. Prosječan unos kalcija je iznosio $653 \pm 296 \mathrm{mg} / \mathrm{dan}$ u 
muškaraca i 528 $279 \mathrm{mg} /$ dan u žena ( $p=0,004)$. Unos kalcija ispod preporučenih vrijednosti od $750 \mathrm{mg} /$ dan je utvrđen u 67,3 \% muškaraca i 77,5 \% žena. Vrlo niski unos kalcija, manji od polovine preporučene vrijednosti, je utvrđen u 18.3 \% muškaraca i 31.0 \% žena. Mlijeko i mliječni proizvodi bili su glavni izvor (više od 80 \%) ukupnog dnevnog unosa kalcija u ispitanika. Nije utvrđena značajna povezanost između indeksa tjelesne mase i unosa kalcija u oba spola. Zaključujemo da je prosječni unos kalcija u naših ispitanika koji žive u domovima za starije osobe ispod preporučenih vrijednosti.

\section{Ključne riječi: unos kalcija, stariji ljudi, domovi za starije osobe}

\section{References}

1. Balk, E.M., Adam, G.P., Langberg, V.N., Earley, A., Clark, P., Ebeling, P.R., Mithal, A., Rizzoli, R., Zerbini, C.A.F., Pierroz, D.D., Dawson-Hughes, B. (2017): Global dietary calcium intake among adults: a systematic review. Osteoporosis International 28 (12), 3315-3324. https://doi.org/10.1007/s00198-017-4230-x

2. Bauer, D.C. (2013): Clinical practice. Calcium supplements and fracture prevention. New England Journal of Medicine 369 (16), 1537-1543. https://doi.org/10.1056/NEJMcp1210380

3. Bolland, M.J., Leung, W., Tai, V., Bastin, S., Gamble, G.D., Grey, A., Reid, I.R. (2015): Calcium intake and risk of fracture: systematic review. British Medical Journal 351 (29), h4580. https://doi.org/10.1136/bmj.h4580

4. Colić Barić, I., Kajfež, R., Šatalić, Z., Cvijetić, S. (2004): Comparison of dietary habits in the urban and rural Croatian schoolchildren. European Journal of Nutrition 43 (3), 169-174. https://doi.org/10.1007/s00394-004-0455-5

5. Colić Barić, I., Šatalić, Z. (2002): Eating patterns and fat intake in school children in Croatia. Nutrition Research 22 (5), 539-551. https://doi.org/10.1016/016228899560194

6. Colić Barić, I., Šatalić, Z., Keser, I. (2006): Nutritional quality of meals in nursing homes and meals on wheels for elderly persons in Croatia. Nutrition and Health 18 (2), 119-125.

7. Croatian Official Gazette (2011): Regulation on food supplements, No 46, Zagreb.

8. Ćurin, K., Marušic, J., Culin, S. (2006): Prehrana u domovima za starije osobe u Splitu. Medica Jadertina 36 (1-2), 23-30.

9. Cvijetić, S., Kovačić, J. (2019): Association between quantitative bone ultrasound and self-reported physical activity in nursing homes residents. European Geriatric Medicine, in press. https://doi.org/10.1007/s41999-019-00183-3

10. Del Valle, H.B., Yaktine, A.L., Taylor, C.L., Ross, A.C. (2011): Dietary reference intakes for calcium and vitamin D. National Academies Press, Washington D.C.
11. Department of Health and Ageing (Australia), National Health and Medical Research Council (Australia), Ministry of Health (New Zealand). (2006): Nutrient reference values for Australia and New Zealand, including recommended dietary intakes. https://www.nhmrc.gov.au/about-us/ publications/nutrient-reference-values-australia-andnew-zealand-including-recommended-dietary-intakes (19.05.2019.)

12. Duque, G., Lord, S.R., Mak, J., Ganda, K., Close, J.J.T., Ebeling, Papaioannou, A., Inderjeeth, C.A. (2016): Treatment of Osteoporosis in Australian Residential Aged Care Facilities: Update on Consensus Recommendations for Fracture Prevention. Journal of the American Medical Directors Association 17 (9), 852-859. https://doi.org/10.1016/j.jamda.2016.05.011

13. European Food Safety Authority (EFSA) (2017): Dietary Reference Values for nutrients Summary report. EFSA Supporting publication, e15121. https://doi.org/10.2903/j.efsa.2015.4101

14. Gennari, C. (2001): Calcium and vitamin D nutrition and bone disease of the elderly. Public Health Nutrition 4 (2b), 547-59.

15. Johnell, O., Kanis, J.A. (2006): An estimate of the worldwide prevalence and disability associated with osteoporotic fractures. Osteoporosis International 17 (12), 1726-1733. https://doi.org/10.1007/s00198-006-0172-4

16. Kaić-Rak, A., Antonić, K. (1990): Food composition tables. Croatian Institute of Public Health, Zagreb.

17. Keser, I., Šatalić, Z., Giljević, Z., Colić Barić, I. (2005): Nutritional value of meals, with particular reference to calcium, in nursing homes in the City of Zagreb. Proceedings of the $3^{\text {rd }}$ Croatian Congress on Osteoporosis, Šibenik.

18. Kruavit, A., Chailurkit, L., Thakkinstian, A., Sriphrapradang, C., Rajatanavin, R. (2012): Prevalence of Vitamin D insufficiency and low bone mineral density in elderly Thai nursing home residents. BMC Geriatrics 12 (1), 49. https://doi.org/10.1186/1471-2318-12-49

19. Mandić-Puljek, M., Mandić, M.L., Perl, A., Kenjerić, D. (2005): Calcium Intake, Food Sources and Seasonal Variations in Eastern Croatia. Collegium Antropologicum 29 (2), 503-507. 
20. Meng. H., Lin, X., Hu, L. (2016): Evaluation of nutritional status and dietary intake in older adults living at home and nursing homes in Dongying, China. Journal of Nutritional Health \& Food Engineering 4 (3), 451-458. https://doi.org/10.15406/jnhfe.2016.04.00134

21. Nordic Council of Ministers. (2004): Nordic nutrition recommendations 2004. Integrating nutrition and physical activity. $4^{\text {th }}$ ed.

22. Papaioannou, A., Santesso, N., Morin, S.N., Feldman, S., Adachi, J.D., Crilly, R., Giangregorio, L.M., Jaglal, S., Josse, R.G., Kaasalainen, S., Katz, P., Moser, A., Pickard, L., Weiler, H., Whiting, S., Skidmore, C.J., Cheung, A.M. (2015):

Recommendations for preventing fracture in long-term care. Canadian Medical Association Journal 187 (15), 1135-1144. https://doi.org/10.1503/cmaj.141331

23. Rodríguez-Rejón, A.l., Ruiz-López, M.D., Artacho, R. (2019): Dietary intake and associated factors in long-term care homes in southeast Spain. Nutrients 11 (2). https://doi.org/10.3390/nu11020266.

24. Rumbak, I., Šatalić, Z., Keser, I., Panjkota Krbavčić, I., Giljević, I., Zadro, Z., Colić Barić, I. (2010): Diet quality in elderly nursing home residents evaluated by diet quality index revised (DQI-R). Collegium Antropologicum 34 (2), 577-585.

25. Šatalić, Z., Colić Barić, I., Cecić, I., Keser, I. (2007): Short food frequency questionnaire can discriminate inadequate and adequate calcium intake in Croatian postmenopausal women. Nutrition Research 27 (9), 542-547. https://doi.org/10.1016/j.nutres.2007.07.001

26. Šatalić, Z., Colić Barić, I., Keser, I., Marić, B. (2004): Evaluation of diet quality with the Mediterranean dietary quality index in university students. International Journal of Food Sciences and Nutrition 55 (8), 589-597. https://doi.org/10.1080/09637480500086141

27. Tang, B.M., Eslick, G.D., Nowson, C., Smith, C., Bensoussan, A. (2007): Use of calcium or calcium in combination with vitamin $\mathrm{D}$ supplementation to prevent fractures and bone loss in people aged 50 years and older: a meta-analysis. Lancet 370 (9588), 657-666. https://doi.org/10.1016/S0140-6736(07)61342-7
28. Uenishi, K., Ishida, H., Kamei, A., Shiraki, M., Ezawa, I., Goto, S., Fukuoka, H., Hosoi, T., Orimo, H. (2002): Calcium requirement estimated by balance study in elderly Japanese people. Osteoporosis International, 13(2), 184-184. https://doi.org/10.1007/s001980170037

29. Vranešić Bender, D., Krznarić, Ž., Reiner, Ž., Tomek Roksandić, S., Duraković, Z., Kaić-Rak, A., Smolej Narančić. S., Bosnir J. (2011): Croatian guidelines for nutrition in the elderly, part I. Liječnički Vjesnik 133 (9-10), 231-240.

30. Warensjö, E., Byberg, L., Melhus, H., Gedeborg, R., Mallmin, H., Wolk, A., Michaëlsson, K. (2011): Dietary calcium intake and risk of fracture and osteoporosis: prospective longitudinal cohort study. British Medical Journal 24, 342, 1473. https://doi.org/10.1136/bmj.d1473

31. Yates, A.A., Schlicker, S.A., Suitor, C.W. (1998): Dietary reference intakes: the new basis for recommendations for calcium and related nutrients, B vitamins, and choline. Journal of the American Dietetic Association 98 (6), 699-706. https://doi.org/10.1016/S0002-8223(98)00160-6

32. Zarowitz, B.J., O'Shea, T., Nance, M. (2014): Clinical, demographic, and pharmacologic features of nursing home residents with Huntington's disease. Journal of the American Medical Directors Association 15 (6), 423-428. https://doi.org/10.1016/j.jamda

33. Zelenik, D., Persuh, T., Jordan, T. (2016): Practical approach to nutritional support in nursing home. Abstracts / Clinical Nutrition ESPEN 14, 42e57.

34. Zhao, J.G., Zeng, X.T., Wang, J., Liu, L. (2017): Association between calcium or vitamin $\mathrm{D}$ supplementation and fracture incidence in community-dwelling older adults. A systematic review and meta-analysis. Journal of American Medical Association 318 (24), 2466-2482. https://doi. org/10.1001/jama.2017.19344 